research in Arctic and sub-Arctic seas is still most intense, with the need for a US research icebreaker and more international experiments being planned for the future.

The Arctic Ocean issue of Oceanus makes good reading, but then so does any other issue of this informative journal. Indeed, as a polar scientist I found earlier numbers more compulsive reading, for example $28(1)$ on marine archaeology, and $28(2)$ on the oceans and national security. I presume, however, that if I practiced marine archaeology for a living, I might be fascinated by the recent volume on the Arctic, and can therefore most highly recommend it and a subscription to the journal as a whole. (Vernon A. Squire, Scott Polar Research Institute, Lensfield Road, Cambridge CB2 1ER.)

\title{
NORTH AMERICAN SEALERS
}

\section{THE WAR AGAINST THE SEALS: A HISTORY OF THE NORTH AMERICAN} SEAL FISHERY. Busch, B. C. 1985. Kingston and Montreal, McGill-Queen's University Press. $374 \mathrm{p}$, illustrated, hard cover. ISBN 0-7735-0578-4. \$29.95.

Briton Cooper Busch wrote this book for the best possible reason. He scoured the libraries for a history of the North American sealing industry, found there was no such thing, so wrote his own. A historian with little personal knowledge of seals, he relied on biologist colleagues for his zoology. They served him well; there is little to fault in his account of the animals themselves. The history is lucid, leading us in time from the late 18th century almost to the present, and covering everywhere from Arctic to sub-Antarctic where American sealers worked. Much of the text concerns the hunt for Bering Sea fur seals and Newfoundland harp seals, which together provided the backbone of the industry, but South American, South African and Southern Ocean stocks too are brought into the picture. Busch writes well of the sealers, their ships and their islands; no less important in his story are catch statistics, details of pelt processing, industrial disputes, markets, and the dealers and entrepreneurs who ultimately determined how many seals would die each year for the industry. A most readable story, marred for me only by a plethora of footnotes requiring frequent excursions to the back pages; if a fact is worth putting in, surely it is worth the trouble of building into the main text. This an essential book for libraries and students concerned with the sealing industry. (Bernard Stonehouse, Scott Polar Research Institute, Lensfield Road, Cambridge CB2 1ER.)

\section{AERIAL SURVEY OF GRAHAM LAND}

WINGS OVER ICE: AN ACCOUNT OF THE FALKLAND ISLANDS DEPENDENCIES AERIAL SURVEY EXPEDITION. Mott, P. G. 1986. Long Sutton, Mott. Illustrated, hard cover.

Here is the long-awaited account of FIDACE, the aerial survey expedition that systematically photographed much of Antarctic Peninsula and adjacent islands some 30 years ago, in the summers of 1955-56 and 1956-57. FIDACE was organized by Hunting Aerosuryeys Ltd on behalf of the British Colonial Office; it was both the first commercially-run Antarctic survey expedition, and the first fully-controlled aerial survey of a sector of Antarctica. Its terms of reference were to take vertical photographs between $62^{\circ}$ and $68^{\circ} \mathrm{S}$, provide a ground control framework for the preparation of accurate maps, and run airborne magnetic profiles in specified areas for geological investigations.

To this end the survey's two amphibian Canso aircraft flew some 130,000 nautical miles, covered 35,000 sq miles of territory, and took about 17,000 photographs. The survey was organized from a base on Deception Island, with ship and helicopter support 